\title{
Japan's Early Industrialization and the Transfer of Government Enterprises: Government and Business
}

\author{
By Masaaki Kobayashi \\ Kanto Gakuin University
}

\section{Introduction}

The role of the central government in Japan's industrialization was a significant one. In the years after the Meiji Restoration of 1868 , the central government promoted industrialization so that Japan might make itself the equal of the advanced nations of the West as quickly as possible. The government's eventual decision to dispose of the factories it had created for this purpose was, in fact, part of its policy of industrial promotion; no such action has taken place in other industrializing nations. This disposal involved the sale to private parties of mines and modern factories set up either prior to 1868 by the Tokugawa government and by the han (feudal domains) or by the Meiji government itself after the Restoration, and was carried out between 1884 and 1896 in accordance with guidelines issued in November 1880 . The government did not sell its armaments factories, postal and telegraph systems, mints, or railroads, but it did dispose of all its silk-reeling, cotton-spinning, and sugar factories, as well as its mines, its iron works, and its shipyards, cement and glass factories.

The beneficiaries of these sales included some of the most important business groups in modern Japan: Mitsui, Mitsubishi, Asano, Kawasaki, Furukawa, etc. The men who headed these businesses at the time the government sold its enterprises were called seisho - i.e., merchants with political affiliations. The term seisho was first used by the Meiji-era journalist Aizan Yamaji in his 1908 work Gendai kinken shi (A History of Modern Economic Power). It was Yamaji's contention that these entrepreneurs were a unique group who rose to power in the early Meiji years at a time when the central government was actively encouraging the growth of private industry.

Since the publication of Yamaji's work, the term seisho has come to refer to businessmen who use personal ties with public officials to their own particular advantage. The fact that it has also been used, almost without exception, to refer to those who purchased the enterprises established by the government has been a serious impediment to a 
rigorous analysis of the Meiji government's policy in this area. But since the Second World War, a substantial number of official documents from the Meiji era have become available; similarly, the dissolution of the zaibatsu after the war made available the records of those organizations. An examination of these materials makes it clear, I believe, that the Meiji government, far from being an omnipotent force, operated from a position of financial weakness; as a result, its industrial policy was, more than anything else, one of trial and error. Japan's rapid industrialization was not the result of unusual prowess on the part of the government; private industry was responsible for this, and the conditions for taking over had already been established by the time the government decided to dispose of the operations it had set up.

It is with this in mind that I would like to examine the Meiji government's disposal of its enterprises, and to consider how private industry responded to this action. A consideration of this process is an essential part of the study of government business relations in the industrialization of Japan. The theme for the sixth annual meeting of the Business History Society of Japan was government business relations, and at this meeting I presented a paper entitled "Japan's Early Industrialization and the Sale of Government Properties". ") This was subsequently published in book form, with the subtitle "Government and Business". 2) This present work is based on that book, and on additional papers I wrote after the book was published. In addition, at the 1978 Fifth Fuji International Conference, which had government business relations as its theme, I was among those who spoke about Japan on the specific topic of "Government Promotion of Manufacturing as a Precondition for Industrialization;" in this case, I dealt with the contributions of Shigenobu Okuma as Finance Minister. ${ }^{3)}$ Similar work has been done by non-Japanese scholars: Thomas $C$. Smith, for example, published a study of the Meiji government's role in industrialization in 1955. ${ }^{4)}$

\section{The Industrial Policy of the Meiji Government}

\section{The Policy of Industrial Promotion: Contents and Structure.}

The Meiji government set as its initial goal not the modernization of preexisting domestic industries, but rather the introduction of modern industries from the West; it was to this end that the Ministry of Industry was established in $1870 . .^{5}$ The ministry was set up at the urging of the kaimeiha, a progressive group of officials that included Shigenobu Okuma, Hirobumi Ito, and Kaoru Inoue, in order to oversee railroads, mines, and heavy industry. The more conservative members of the 
government, a group known as the hoshuha that included Tomomi Iwakura, Toshimichi Okubo, and Masaomi Hirosawa, stressed the need for Japan to wrest itself from the pressure of the West and build up its military strength; accordingly, they opposed the progressives' preference for the development of railroads, communication facilities, and the like. Policy was developed in the context of this clash of priorities - a clash exacerbated by regional loyalties, especially involving those from the four han (Satsuma=Kagoshima prefecture, Choshu=Yamaguchi prefecture, Tosa=Kochi prefecture and Hizen=Saga prefecture) who were most instrumental in bringing about the Meiji Restoration.

Despite these ideological differences, the progressives did succeed in mustering enough conservative support to have the Ministry of Industry established. There are two extant position papers urging the establishment of this ministry, both unsigned but most likely the work of Okuma. ${ }^{6}$ In the first of these papers, the author states that "Although the British people value their personal independence and do not look with favor on governmental interference, in Japan we must have a powerful public agency to direct the process of industrialization." In the second, he wrote that:

Industrialization is the quickest way to increase the wealth of a nation. A country enjoys prestige only to the extent that its government is firmly established, it possesses all the iron (modern) machinery, and it encourages industry. Industry itself is a particularly vital factor in increasing a nation's military strength.

The two papers reflect the views of a man who, for one thing, knew a great deal about England. Okuma, by birth a high-ranking member of the samurai (warrior) class, had studied both Dutch and English. There were, in the early Meiji years, few officials in the government who could read English and acquaint themselves thereby with conditions in the West; those that could were highly regarded. Okuma played an indispensible role in the development of relations with England; this allowed him to dominate early Meiji industrial policy despite the fact that he came from Hizen, the smallest of the four aforementioned han. His foreign expertise also explains his elevation, before Ito and Inoue, to the sangi (Council of Advisors), which oversaw the main operations of the central government between 1869 and the establishment of the cabinet system in 1885 .

In late 1871 , the Meiji government sent a group of no less than fifty officials headed by Tomomi Iwakura to the United States and Europe. 
This Iwakura Mission, as it is known, lasted twenty-two months, and had as its ostensible objective preliminary negotiations to revise the "unequal treaties" of 1858; the members of the mission were also instructed to examine conditions and institutions in the West as a way of assessing Japan's own international fortunes. Among those sent were Finance Minister Okubo and Vice-Minister of Industry Ito, as well as experts in the iron and shipbuilding industries. Okuma was not among those sent, though the trip was his idea. Okubo, initially a conservative, was to join the ranks of the progressives after spending four months in England and observing, often to his considerable surprise, the extent of that nation's power and wealth.

Shortly after returning to Japan in November 1873, Okubo succeeded in having a Ministry of Home Affairs set up. Okubo himself took the position of Home Affairs Minister, gave the Finance Ministry to Okuma, and the Ministry of Industry to Ito. Okubo was from Satsuma, Okuma was from Hizen, and Ito was from Choshu; all three now were progressives. Their new positions meant that such regional differences as had existed among these men had been overcome, and that the structure had been established for a strong policy of industrial promotion.

It was Okubo's understanding that the source of England's wealth was the fact that, having used the Navigation Acts and the Act for the Encouragement of Trade to protect domestic private industry, that nation then adopted a policy of free trade. Since England and Japan were geographically similar, Okubo concluded that England would be the most suitable model for development. After conferring with Okuma, he initiated a policy of encouraging the shipping industry by offering financial aid to private shipping firms. Okubo's first action in this area was to shut down the Nihonkoku Yubin Jokisen Kaisha, a shipping company set up under public subsidy in 1872, and to give the company's thirteen ships to Yataro Iwasaki, the founder of Mitsubishi and head of his own steamship company. Okubo also promised Iwasaki annual subsidies of 250,000 yen for fifteen years. Okubo's largesse enabled Iwasaki to dominate Japan's sea lanes and eliminate Western shipping companies both from Japanese waters and from the Shanghai route; it also marked the beginning of close ties between Okuma and Iwasaki.

The Home Affairs Ministry set up sheep farms, agricultural experimental stations, farm machinery factories, and factories to produce raw silk, cotton, and woolen articles; the aim of the ministry was to foster agricultural businesses and facilitate the processing of agricultural products. Accordingly, many of its operations were set up in areas where, for example, raw silk and cotton were produced on a large scale. The 
ministry drew up plans to build 250 cotton-spinning factories in the major raw cotton producing areas, though only two were eventually constructed. With the exception of the sheep farms, the operations set up by the Ministry of Home Affairs were intended to serve as models for the modernization of preexisting industries; but these industries had enjoyed a rather consistent process of development prior to the Meiji Restoration, and the ability of the government's factories to function as models was therefore to prove problematic at best.

The most important of the six bureaus in the Ministry of Home Affairs were those for industrial promotion and public order. Domestic unrest, in addition to the fact that these two bureaus had nothing in common, prevented the ministry from accomplishing anything with regard to industrial promotion other than securing a place for Japan's shipping industry. Okubo himself, having directed the suppression of the Satsuma Rebellion in 1877 , was assassinated in May 1878 by disgruntled ex-samurai; ironically, his death came shortly after he had drawn up plans to provide training and financial help for unemployed members of the former warrior class.

With Okubo's death, Okuma's position was weakened, though not before he too pushed through policies to the advantage of private business. As Vice-Minister of Finance, Okuma had been responsible for the new land-tax system that went into effect in 1873. Whereas the peasantry had previously paid a portion of their rice harvest as tax, it was now required to pay an annual cash sum equal to 3 (later 2.5 ) percent of the assessed value of their land. The new system forced peasants to sell their rice crops before the tax was due. Among those to profit from this was the House of Mitsui, which used its Mitsui Bank and Mitsui Bussan to lend money to peasants in return for their rice as collateral. The transaction was immensely profitable for Mitsubishi, which also profited from shipping the rice.

In 1875 , Okuma presented a number of proposals to strengthen Japan's economic position vis-a-vis the West. These proposals included an increase in the indirect tax, a stress on the use of domestically produced goods, government inspection of imported goods at the time of purchase, the issuance of government bonds, and the disposal of public enterprises. His ideas were modeled after British mercantilism. The same year, Okubo proposed that Japanese merchants bypass Western traders altogether when exporting Japanese merchandise; this led to the foundation, in 1880 , of Doshinsha, a company which exported raw silk directly to the West, and to the direct export of coal from the government-run coal mine at Miike. Mitsui Bussan handled shipping for both the silk 
and the coal.

2. Public Enterprises and Changes in Government Policy.

The Ministries of Industry and Home Affairs were the main agencies through which the Meiji government pursued its policy of encouraging industrial development. In order to examine the actual workings of this policy, I would like to consider two public enterprises: the Ministry of Industry's Kamaishi Iron Works, and the Ministry of Home Affairs' Tomioka Filature. The government invested heavily in both of these "model" operations, which were equipped with the most modern Western technology available.

The Kamaishi Iron Works was established in Kamaishi, Iwate prefec. ture, under British technical guidance and with two British blast furnaces capable of producing twenty-five tons of pig iron daily. Prior to the Meiji Restoration, Takato Oshima, a Nanbu han official who was later to join the Iwakura Mission, had set up an iron works with three blast furnaces at the same location. The Meiji government replaced these furnaces with the British machinery, and also imported steam locomotives to transport the ore. In addition, it absorbed 10 percent of the thirty million yen required to set up the government-run factories and, in September 1880, began iron production in order to supply other industries with the necessary raw material.

The British blast furnaces were designed to use coke for fuel, but in the absence of that resource in the Kamaishi area, the factory was forced to use charcoal instead. Reliance on charcoal was less than satisfactory, but even this became impossible when a fire destroyed the charcoal plant on which Kamaishi relied. Production came to a halt in December 1880. The factory reopened in February 1882, then stopped production again in September of that year. The Ministry of Industry thereupon concluded that there were, after all, not enough iron ore deposits to warrant continued operation of the factory; it shut down Kamaishi in December 1882 .

Tomioka Filature opened in October 1872 under the auspices of the Ministry of Civil Affairs (Minbu-sho); it was later placed under the jurisdiction of the Home Affairs Ministry (Naimu-sho) when the Ministry of Civil Affairs was abolished. Tomioka was set up with French technical assistance, and began operations with 300 reeling units and a work force of 450. Its size was immense, especially given the fact that Japanese rural silk producers of the time could manage operations of at most forty reeling units. Silkworm cocoons being in short supply in the Tomioka area, the filature was forced to have them shipped in at very 
high prices. Production costs were high, efficiency was low, and Tomioka's debts steadily accumulated. Hirobumi Ito, who succeeded Okubo as Home Affairs Minister, was unperturbed by this rather lackluster record. At one point, he told Tomioka's director, Kenzo Hayami, that losses at Tomioka were unavoidable because the filature's main purpose was less to produce at a profit than to serve as a model to encourage similar operations. Hayami responded to the effect that people were most interested in how Tomioka fared financially, and that the filature would be ineffective as a model if it operated in the red, regardless of the quality of its output.

Kamaishi and Tomioka had two features in common. In both cases, the government did attempt to locate the factories in areas where the necessary raw materials were in abundance; in neither case did supplies prove sufficient, and the remote locations only made it that much more difficult to get the finished products to market. Both factories were also totally dependent on Western technology and advisors. Whether in fact such dependence was avoidable seems doubtful. The Ministry of Industry's Bureau of Manufacturing operated factories to produce machinery and chemicals for publicly-run factories, usually without direct foreign assistance. These efforts usually amounted, though, to the government simply supplying demands it had created itself, so that the factories rarely operated at a profit; worse still, their products were generally inferior to the Western goods on which they were modeled. The Yokosuka shipyard did make water wheels for the Aichi Spinning Mill, with satisfactory results; both places were run by the government. But when the mill ordered ten spinning looms from the government's Akabane Machine Works, the first machine yielded such poor output that the subsequent order was canceled.

Apart from production problems, publicly-run factories were also saddled with exceptionally high personnel expenditures for the foreign technicians and government bureaucrats who ran them; unlike private factories, these operations rarely took in enough income to meet their expenses. They were, in addition, beset by an overabundance of official regulations, and the officials who ran them were sufficiently arrogant to drive away most of the people who might otherwise have sought guidance from these operations. The government had not intended this, and in fact had expected to profit in several ways from its enterprises: public shipbuilding, mining, machinery and railroad operations were supposed not only to inspire others to pursue similar activity but to turn a profit as well.

Besides that situation, private producers did not seem to find favor 
with the government, so that criticism of the public factories became increasingly common. Yukichi Fukuzawa observed that "If the government tries to increase the wealth of the nation by running the same type of business operated by private parties, all it does is compete with them." Similarly, Ukichi Taguchi offered the following critique:

What do we mean by government encouragement of industry? Do we mean that the government ought to actually produce things? In fact, public enterprises compete with and hinder private business.

Such criticism was not limited to those outside the government. In January 1877 , some Meiji officials began to call for a reorganization of government enterprises, including the Ministry of Finance's minting and printing operations and the Hokkaido Development Agency, and for their redistribution under the exclusive jurisdiction of the Ministries of Industry and Home Affairs. The previous month, Okubo had suggested that these two ministries be combined, reliance on Western advisors discontinued, and that the structure of the ministries be changed. The last two proposals were carried out, but the Satsuma Rebellion, which lasted from February to September of 1877 , effectively prevented any consideration of the first idea. Suppressing the rebellion cost the government over forty million yen, and organizational considerations were forced to take second place to financial ones. The haphazard accounting methods previously used for public factories were revised. As of fiscal 1878 (i.e., July 1877 to June 1878), all government enterprises were to be considered separately, and each was made responsible for its fixed and working capital. The purpose of this reform was to make it clear which were operating at a profit and which were in the red - and, apparently, to get rid of the latter.

The government's financial problems seriously affected its industrial policy; by the middle of 1878 , funds for industrial promotion were being reduced. In November 1880, the government issued an ordinance specifying tax increases, a one-million yen reduction in the public treasury, the end of protection for private industry, and, finally, guidelines for the disposal of public enterprises. In April 1881, the government attempted to reorganize its enterprises, once and for all, and to reduce expenditures by consolidating them under the new Ministry of Agriculture and Commerce. This ministry was obviously intended to handle all industrial promotion activities from that point on. It took over the Home Affairs Ministry's Agricultural Promotion Bureau, the Finance Ministry's Commerce Bureau, and, with the demise of the Hokkaido Development 
Agency in March 1882, all projects for the development of Hokkaido; it also set up its own Bureau of Manufacturing.

\section{The Transfer of Government Enterprises: the Three Phases.}

In May 1880, Shigenobu Okuma presented the Meiji government with a plan to stabilize Japan's currency by floating a fifty-million yen foreign bond and using the returns to convert paper money into specie. At the same time, he recommended that the government dispose of the enterprises it had set up to promote industrial development. Okuma divided these operations into three categories: those vital for the national welfare (munitions factories, mints, etc.); those that required a high level of spending and sophisticated technology (metallurgy and printing operations, communications, etc.); and those set up as models to promote industrial modernization. According to Okuma's reckoning, the sale of fourteen of the "model" factories would yield the government four million yen, which could be used to help redeem the national debt. These fourteen consisted of all the textile operations set up by the Home Affairs Ministry (at Senju ${ }^{7)}$, Aichi, Hiroshima, Shinmachi, and Tomioka), the Ministry of Industry's factories in Akabane (for machinery and lacquerware), Fukagawa (for cement and brick), Hyogo, Nagasaki, and Shinagawa, and the carbolic acid and sugar plants that were run by the Hokkaido Development Agency.

Okuma appended guidelines to his plan, with the warning that, unless the factories were sold carefully, the results would be inequitable and the government would end up losing much of what it had invested. Preventing the latter was clearly the highest priority in these guidelines, which were virtually the same as those announced in November of that year. More important than selling the factories to people capable of running them was selling them to people capable of buying them at what the government considered a decent price. The official terms of disposal required that the government accept competitive bids on each factory, that the fixed capital assets be paid for in equal annual installments, and that the purchaser make immediate payment for the factory's working capital assets.

There were few prospective buyers at this point - none, in fact, aside from four who bid on the profitable spinning mill at Shinmachi. There were, to be sure, any number of potential buyers for the government's railroad and mining interests; but these operations were in the black, and were not on the list of disposable enterprises. Moreover, they represented precisely those areas where the Ministry of Industry had invested most heavily; during the fifteen years of its existence, the ministry put 50 
percent of its industrial investments into railroads and another 30 percent into mining.

The guidelines for the disposal of public enterprises applied to the holdings of the Ministries of Industry and Home Affairs and to the Hokkaido Development Agency. Serious problems arose, however, when the last of these attempted to sell operations under its jurisdiction in ways contrary to the guidelines. The government had invested fully fourteen million yen in this agency since 1869 , and all of its operations were supposed to be sold for a total of 380,000 yen, to be paid back without interest over a thirty-year period. But both the head of the Hokkaido Development Agency, Kiyotaka Kuroda, and the prospective buyers, Tomoatsu Godai and Sadanori Yasuda, were originally from Satsuma; this apparent regional favoritism led to increased pressure on the government to accelerate plans to establish parliamentary government. The government responded by prohibiting the planned sale of the Hokkaido properties and postponing their disposal until 1886; at the same time, many officials suspected that the furor over the sale was largely the work of Okuma, Fukuzawa, and Iwasaki of Mitsubishi. Okuma, who had incurred the wrath of many with his calls for an early adoption of a constitution and a parliamentary system, and also angered those who wanted to end Western influence with his call for a foreign bond flotation, was expelled from the government in 1881. The Ministers of Home Affairs and Agriculture and Commerce, among others, were also forced to resign. The departure of Okuma meant the end of the government's direct support to Mitsubishi and its announcement that the Diet would open in 1890 effectively silenced demands for early establishment.

The failure to find suitable buyers for any of the enterprises up for sale, despite the government's explicit directions that they be sold as quickly as possible, prompted the government to announce, in July 1884 , that it would sell all its mining operations except those at Sado, Ikuno, Miike and Ani (technological drawbacks at the Ani operation led to its subsequent inclusion among those mines up for sale). In October of that year, the government also abolished the obviously ineffective disposal guidelines, and issued instructions instead that each sale be handled separately.

The decision to sell publicly-run mines marks the beginning of the second phase of the government's attempt to dispose of its enterprises. As Table 1 indicates, most government enterprises were sold during this period (i.e., the mid 1880s), which also marked the completion of Finance Minister Masayoshi Matsukata's deflationary policies. Matsukata's 
Table 1 Transfers of Main Government Enterprises

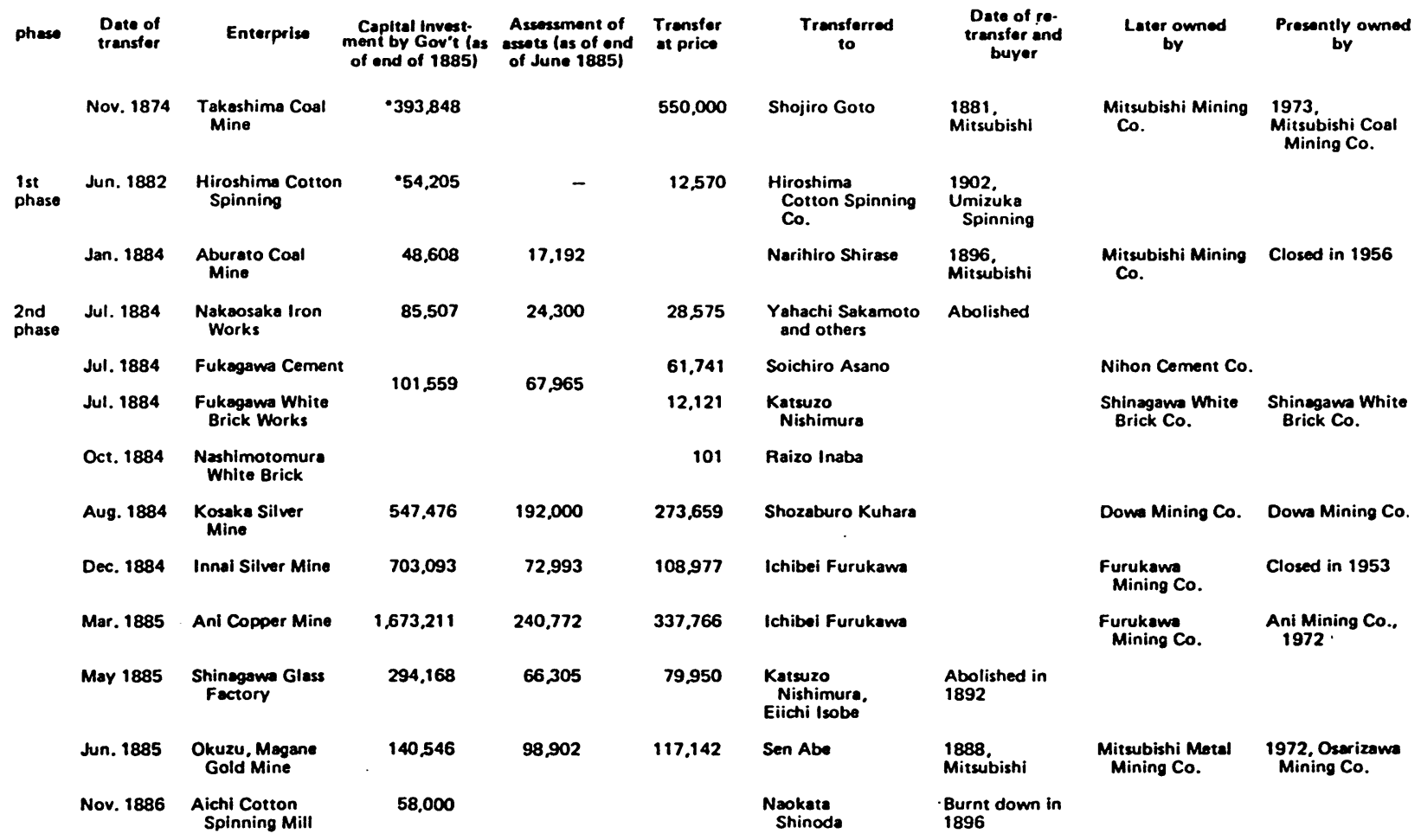




\begin{tabular}{|c|c|c|c|c|c|c|c|c|c|}
\hline phaso & $\begin{array}{l}\text { Date of } \\
\text { transfer }\end{array}$ & Enterprise & $\begin{array}{l}\text { Capltal Invest- } \\
\text { ment by Gov't (as } \\
\text { of end of } 1885 \text { ) }\end{array}$ & $\begin{array}{l}\text { Assossment of } \\
\text { assots (as of ond } \\
\text { of June 1885) }\end{array}$ & $\begin{array}{l}\text { Transfer } \\
\text { at price }\end{array}$ & $\begin{array}{c}\text { Trensferred } \\
\text { to }\end{array}$ & $\begin{array}{l}\text { Date of re- } \\
\text { transfer and } \\
\text { buyer }\end{array}$ & $\begin{array}{l}\text { Later owned } \\
\text { by }\end{array}$ & $\begin{array}{c}\text { Presently owned } \\
\text { by }\end{array}$ \\
\hline & Dec. 1886 & Sapporo Brewery & - & - & 27,672 & Kihachiro Okura & $\begin{array}{l}1887 . \\
\text { Sapporo Beer }\end{array}$ & $\begin{array}{l}\text { Sapporo Brewery } \\
\text { Co. }\end{array}$ & $\begin{array}{l}\text { Sapporo Brewery } \\
\text { Co. }\end{array}$ \\
\hline & May 1887 & $\begin{array}{l}\text { Shinmachi Slik } \\
\text { Spinning Mill }\end{array}$ & 138,984 & - & 141,000 & Mitsui & Yasushi Asaba & $\begin{array}{l}\text { Kanegafuchi } \\
\text { Spinning Co. }\end{array}$ & $\begin{array}{l}\text { Kanegafuchi } \\
\text { Spinning Co. }\end{array}$ \\
\hline & Jun. 1887 & $\begin{array}{l}\text { Nagasaki } \\
\text { Shipyard }\end{array}$ & $1,130,949$ & 459,000 & 459,000 & Mitsubishi & & $\begin{array}{l}\text { Mitsubishi Heavy } \\
\text { Industries Co. }\end{array}$ & $\begin{array}{l}\text { Mitsubishi Heavy } \\
\text { Industries Co. }\end{array}$ \\
\hline & Jul. 1887 & Hyogo Shipyard & 816.139 & 320.196 & 188,029 & Shozo Kawasaki & & $\begin{array}{l}\text { Kawasaki Heawy } \\
\text { Industries Co. }\end{array}$ & $\begin{array}{l}\text { Kawasaki Heaw } \\
\text { Industries Co. }\end{array}$ \\
\hline & Dec. 1887 & $\begin{array}{l}\text { Kemaishi Iron } \\
\text { Works }\end{array}$ & $2,376,625$ & 733,122 & 12,600 & Chobei Tanaka & $\begin{array}{l}\text { 1924, Kamaishi } \\
\text { Mining Co. I }\end{array}$ & Nippon Steel Co. & Nippon Steel Co. \\
\hline & Jan. 1888 & $\begin{array}{l}\text { Mite Agricultural } \\
\text { Machine } \\
\text { Factory }\end{array}$ & - & - & 33,795 & $\begin{array}{l}\text { Shun Koyasu } \\
\text { and others }\end{array}$ & $\begin{array}{l}\text { Tokyo Machine } \\
\text { Making Co. }\end{array}$ & $\begin{array}{l}\text { Tokyo Machine } \\
\text { Manufacturing } \\
\text { Co. }\end{array}$ & $\begin{array}{l}\text { Tokyo Machine } \\
\text { Manufacturing } \\
\text { Co. }\end{array}$ \\
\hline & Mar. 1888 & Banshu Grapeyard & $\bullet 8,000$ & - & 5,377 & Masana Maeda & & & \\
\hline \multirow[t]{6}{*}{$\begin{array}{l}\text { 3rd } \\
\text { phase }\end{array}$} & Aug. 1888 & Miike Coal Mine & 757,060 & 448,549 & $4,590,439$ & Hachiro Sasaki & 1889, Mitsui & Mitsui Mining Co. & $\begin{array}{l}\text { 1973, Mitsui } \\
\text { Coal Mining Co. }\end{array}$ \\
\hline & Nov. 1888 & $\begin{array}{l}\text { Horonai Coal } \\
\text { Mine and } \\
\text { Railway }\end{array}$ & $\bullet 2,291,500$ & - & 352,318 & $\begin{array}{l}\text { Hokkaido Coal } \\
\text { Mine and } \\
\text { Railway Co. }\end{array}$ & 1899, Mitsui & $\begin{array}{l}\text { Hokkaido Coal } \\
\text { Mine and } \\
\text { Steamship Co. }\end{array}$ & $\begin{array}{l}\text { Hokkaido Coal } \\
\text { Mine and } \\
\text { Steamship Co. }\end{array}$ \\
\hline & Mar. 1890 & $\begin{array}{l}\text { Monbetsu Sugar } \\
\text { Refining Mill }\end{array}$ & $\bullet 258,492$ & - & 994 & Kuninari Date & $\begin{array}{l}\text { 1895, Sapporo } \\
\text { Sugar Refin- } \\
\text { ing Co. }\end{array}$ & Dissolved in 1896 & \\
\hline & Sep. 1893 & Tomioka Filature & $\bullet 310,000$ & - & 121,460 & Mitsui & $\begin{array}{l}\text { 1902. Hare \& } \\
\text { Co. }\end{array}$ & $\begin{array}{l}\text { Katakure Silk- } \\
\text { reeling Co. }\end{array}$ & $\begin{array}{l}\text { Katakura } \\
\text { Industry Co. }\end{array}$ \\
\hline & Sep. 1896 & Sado Gold Mine & $1,419,244$ & 445,250 & $2,560,926$ & Mitsubishi & & $\begin{array}{l}\text { Mitsubishi Metal } \\
\text { Mining Co. }\end{array}$ & $\begin{array}{l}\text { 1973, Sodo } \\
\text { Mining Co. }\end{array}$ \\
\hline & Sep. 1896 & $\begin{array}{l}\text { Ikuno Silver } \\
\text { Mine }\end{array}$ & $1.760,866$ & 866,752 & & & & & Closed in 19 \\
\hline
\end{tabular}

Notes: Figures marked with - indicate total investments made before transfer. As for the first, second and third phases.

Figures marked with indicate total
refer to explanations in the article. 
stress on fiscal retrenchment and his reorganization of the currency system finally put the Meiji government on a sound financial footing, even if the treasury's depleted resources were not fully recovered. ${ }^{8}$ Most operations disposed of during this period were sold interest-free and under long-term payment schedules; in addition, purchasers were not required to cover the cost of the working capital involved.

Factories during this second phase were often sold on a trial basis to determine whether the potential buyer would be able to keep the operation going. The factories were therefore often leased for one to two years, then turned over to the buyer completely if results were satisfactory. Cement works, for example, were leased for 50 percent of net profits and, if the lessee was successful, sold under a twenty-five-year payment schedule; for shipyards, 10 percent of profits and a fifty-year schedule were required. Mines required immediate payment, but were sold cheaply; the Kamaishi Iron Works, for example, were sold for just 12,600 yen, despite the fact that the government had invested fully $2,400,000$ yen into the operation.

More important during this period than the terms of sale, however, was the kind of buyer the government usually selected. Shozo Kawasaki, who purchased the Hyogo Shipyard, was a merchant shipper whose nationalistic fervor led him to begin building Western-style ships, first in the Tokyo area in 1878 and then in Hyogo in 1881. The government decided not to sell the Hyogo Shipyard during the first disposal attempt in 1881 , fearing that it would end up in the hands of Western merchants, and then launched an expansion of the facilities. A steam-powered reflotation dock was installed in 1883, and machinery to build steel ships was added. The shipyard went under the jurisdiction of the Ministry of Agriculture and Commerce following the abolition of the Ministry of Industry in December 1885; shortly thereafter, Kawasaki requested that it be leased to him, stressing his extensive experience in ship construction and his commitment to building Western-style ships of high quality. Kawasaki also noted that the government had already leased its Nagasaki Shipyard to Mitsubishi, and that leasing Hyogo to him would balance that out.

The decision to lease to Kawasaki was made about two months later the only obstacle being that Tomiji Hirano, who also ran a shipbuilding operation, had submitted a similar request. The government first proposed that the two run Hyogo jointly; this suggestion came to naught, partly because Hirano had been a direct vassal of the Tokugawa Bakufu and Kawasaki was from Satsuma, one of the han that had spearheaded the overthrow of the old regime, and the two were hardly likely to act 
cooperatively. More important than this, probably, is the fact that Hirano had already been the beneficiary of considerable public largesse (receiving, for example, lease of the publicly-owned land of Ishikawajima), while Kawasaki had substantial experience in shipbuilding without being under the government's protection. Both parties did well in the end: Kawasaki's operations eventually became Kawasaki Heavy Industries, while Hirano's became Ishikawajima-Harima Heavy Industries. ${ }^{9}$ )

Other examples bear mention as well. Katsuzo Nishimura, who purchased the government's white brick works in Fukagawa, had been a retainer who, in the Bakufu's last years, experienced munitions trading and brick manufacturing. He opened a new brick works after the Restoration, and was given a lease on the government's operation on the basis of this experience. Soichiro Asano bought the cement works in Fukagawa; today, Nihon Cement Company. Asano sold fuel in Tokyo and Yokohama after the Restoration. In this capacity, he supplied the government's cement works with coke, and thereby was able to purchase the operation.

Chobei Tanaka, the purchaser of the Kamaishi Iron Works, had been an iron merchant before 1868 , and after the Restoration was a supplier for the Japanese army and navy. When Kamaishi went up for sale, Tanaka leased it through his son-in-law. After considerable experimentation, he was able to produce material of high quality, using the charcoal and iron ore deposits in the vicinity of the operation and relying on a stone blast furnace built before 1868; he also repaired an iron blast furnace which the government had abandoned. Tanaka's subsequent success was striking: when the government opened its Yawata Iron Works in 1901, his Tanaka Iron Works (now Kamaishi Factory of Shin Nihon Seitetsu, Japan Steel Corporation) already dominated the industry, supplying, as of 1900,72 percent of the nation's pig iron. ${ }^{10)}$

The government's mines at Ani and Innai were sold to Ichibei Furukawa, who had served as manager for the powerful House of Ono around the time of the Meiji Restoration, and handled their silk-reeling and mining operations; the latter included the Ani and Innai mines. These mines went into the government's hands when the House of Ono collapsed in 1874, but Furukawa held on to their Kusakura Copper Mine and, in 1877, acquired Ashio Copper Mine. By 1883, Furukawa's copper mines dominated copper production in Japan, and this enabled him to buy the Ani and Innai operations; it was also the basis for the Furukawa Kogyo (Furukawa Mining Company), the origin of what is now Fujitsu.

The third phase in the disposal of government enterprises began with the issuance of regulations governing the sale of the Miike Coal Mine. 
This phase included the sale of the Sado Gold Mine, Ikuno Silver Mine, and the Osaka Refinery. The Miike, Sado and Ikuno mines were the three most profitable such operations owned and operated by the government. The disposal of Tomioka Filature, and Horonai Coal Mine and Railroad run by the Hokkaido Development Agency belonged to this phase. Terms for sale in this period were considerably stricter than before. Competitive bidding was once again required, and places like the Miike Coal Mine went for high prices. A distinguishing feature of this phase was that Mitsui and Mitsubishi were the major purchasers.

\section{Sales to Mitsui and Mitsubishi}

\section{Sales to Mitsubishi.}

Mitsubishi acquired a government enterprise at first, but indirectly, when it bought the Takashima Coal Mine from its original purchaser, Shojiro Goto, in 1881; thereafter, it bought the Okuzu and Magane gold mines, the Nagasaki Shipyard, the Sado and Ikuno mines and the Osaka Refinery. The Takashima Coal Mine was opened in June 1863 as a joint effort by Hizen han and Glover and Company, a British mercantile firm; it was Japan's first Western-style coal mine. The Meiji government, anxious to avoid dependence on foreign capital, bought the operation in January 1874 for 400,000 dollars from the Netherlands Trading Company, which had taken over the operation and assumed Hizen's liability upon the collapse of Glover and Company in 1870. The government sold the mine to Shojiro Goto, a former Vice-Minister of Industry, in 1874 for 550,000 yen. In accordance with the first disposal guidelines, 200,000 yen of this was to be paid immediately, and the remainder was to be paid over a thirty-five-year period. Unable to make the down payment with his own resources, Goto borrowed funds from Jardine, Matheson and Company, to whom he granted production and marketing rights; none of this was consistent with the government's desire to avoid foreign dependence.

Goto's predicament came to the attention of Yukichi Fukuzawa, who, as a proponent of the early establishment of parliamentary government, saw in Goto a politician whose support might prove useful. Accordingly, Fukuzawa conceived the idea of having Mitsubishi take over the Takashima operation as a way of extricating Goto from his difficulties. Fukuzawa was on good terms with Mitsubishi's Heigoro Shoda, the latter having attended his Keio-Gijuku (now Keio Gijuku University); negotiations between the two were successful, as a result of which Mitsubishi founder Yataro Iwasaki bought the mine for 970,000 yen. ${ }^{11}$ ) 
The price notwithstanding, Mitsubishi did well by the transaction. Takashima was at the southern tip of the Japanese archipelago, so that transport on Mitsubishi's ships to Shanghai for sale was relatively easy. Simultaneously with the purchase, Mitsubishi obtained retail rights for the coal, previously handled by Jardine, Matheson and Company, and the commission therefrom; and transporting Takashima's coal made it possible for Mitsubishi's ships to continue to operate even in winter. Finally, acquisition of Takashima served as an incentive for Mitsubishi to acquire other mines on Kyushu, and to use Takashima as an experimental operation in which modern methods of organization, labor management and production could be introduced. Mitsubishi was thereby able, over time, to replace foreign advisors with its own personnel.

Yataro Iwasaki had first ventured into the shipping business immediately after the Meiji Restoration. Iwasaki had been a low-level functionary in Tosa han and had managed the han's commercial office, Tosa Kaiseisha. When Tosa closed its offices in Osaka in October 1870, the commercial office was renamed Tsukumo Shokai and given three ships to run. With the abolition of the han structure in July 1871, Tsukumo Shokai took over a substantial foreign debt incurred by Tosa on the basis of the credit of foreign merchants to Iwasaki, and Iwasaki used this action to acquire two of the ships for himself. The office was renamed Mitsukawa Shokai in January 1872, then Mitsubishi Shokai in March 1873. Iwasaki probably gained complete control of the operation some time in $1874 .{ }^{12}$ ) Thereafter, he obtained a government contract to transport troops, arms, and military supplies, and for this purpose was given thirteen imported ships. Public assistance for Mitsubishi enabled the company to compete successfully with the foreign and domestic shipping companies, and in 1875 Mitsubishi set up its own small shipyard, Mitsubishi Seitetsusho, in Yokohama, to repair ships. The shipyard was set up as a joint venture with one foreign merchant, but by August 1879 Mitsubishi was running it alone. As of 1877, Mitsubishi had received almost four million yen in subsidies from the government; this favoritism came to an abrupt halt in 1881 with the departure of Shigenobu Okuma from the government and the rise of those opposed to Mitsubishi's increasing dominance of Japan's shipping industry. It was widely believed that Mitsubishi had used the funds given by the government not to develop its shipping operations but to buy the Takashima Coal Mine, to finance loans to others, and the like. In February 1882, therefore, the government ordered Mitsubishi not to engage in any business other than shipping, not to charge excessive shipping fees, and to put more effort into ship-repair activities. In July of the same 
year, the government dealt a further blow to Mitsubishi's fortunes by setting up (with financial backing from Mitsui) the Kyodo Unyu Kaisha, with commissioned admirals appointed president and vice-president, as a direct competitor to Mitsubishi's shipping business.

Despite this apparent hostility, the government on its own initiative decided to lease its shipyard at Nagasaki to Mitsubishi in June 1884. It had been widely expected that the Nagasaki operation would either be taken over by the navy or leased to Kyodo Unyu Kaisha; the government's action prompted some to believe that this was simply another attempt to reduce Mitsubishi's influence, since the shipyard was deeply in debt. ${ }^{13)}$ In fact, though, the decision was a shrewd attempt to improve the fortunes of the shipyard. In a report issued in February 1886, the government cited the desirability of leasing the shipyard - whose losses had mounted since the decline in business in Nagasaki harbor after the Satsuma Rebellion - to a powerful company capable of turning the situation around; it also indicated the need to find a company with the means to excavate the harbor near the shipyard and build a tunnel between the shipyard's two sections.

Iwasaki had already suggested such a move to the government; in a petition dated June 12,1884 , he stated simply that "Since the operation (of the shipyard) has much in common with what we do, I would like to have it leased to us for twenty-five years." In fact, an examination of the shipyard's records for June to December 1883 reveals that the overwhelming portion of its repair business was for ships owned by Mitsubishi; it was, practically speaking, already a Mitsubishi enterprise. Thus on June 23 , it was approved for lease to Iwasaki, who was able to keep the place running normally upon taking it over on July 7, 1886, owing to his own ship repair operation in Yokohama. Iwasaki promptly sent engineers, workers and management personnel from Yokohama to Nagasaki. Iwasaki had recruited Western engineers and advisors in Yokohama, whose operations were supervised by a British expert, a Glasgow-born engineer, J.F. Calder.

When Yataro Iwasaki died on February 7, 1885, his brother Yanosuke took over the business; on April 25, 1887, he submitted a request that the Nagasaki Shipyard be sold to Mitsubishi. Citing the outdated and insufficient nature of the present facilities and the advisability of both replacing equipment and building steel ships, he suggested a price of 459,000 yen, to be paid over a fifty-year period. This was approved on June 7, whereupon Yanosuke submitted a second petition, asking for a reduction in price; the government responded with a price of 91,000 yen to be paid immediately in full. With this, the shipyard 
passed completely into Mitsubishi's hands, and the foundation for Mitsubishi Heavy Industry was laid. In 1885, the government forced the merger of Mitsubishi's shipping operations with the Kyodo Unyu Kaisha; the result was Nihon Yusen Kaisha (N.Y.K.), and the withdrawal of Mitsubishi from the shipping business. Mitsubishi Sha, as the organization was known at that point, was now free to concentrate on its mining operations at Takashima and its shipbuilding operations at Nagasaki.

The Sado Gold Mine and Ikuno Silver Mine went first under the jurisdiction of the Ministry of Agriculture and Commerce following the abolition of the Ministry of Industry, and then the Finance Ministry. At the end of 1884 , they were transferred to the Imperial Household. The Osaka Refinery, also transferred, was refurbished with the newest available equipment in 1889 , and handled the output of these mines. The Aburato Coal Mine was put under the management of the Sado Mine.

Consideration of the sale of these operations was first brought up at an imperial audience in April 1896, when Michitoshi Iwamura, head of the Bureau of Imperial Property, declared that "properties like mines which do not show a stable record of profit ought not to belong to the emperor," and argued for their disposal. The managers of the mines and the refinery protested, insisting that their businesses were profitable enough; they voiced their opinions in newspapers, whereupon the topic became widely discussed. Newspapers took the position that the three places could hardly be sold together, since only the Sado Mine showed a solid record of profit, and that, though the sale of the Ikuno Mine was reasonable enough, disposing of the Osaka Refinery would be unwise. The refinery, it was said, ought to be available for use by all who needed it, and ought not to be the exclusive property of one business.

The prospective sale of these properties began to take on the dimensions of a scandal akin to that which surrounded the disposal of the operations in Hokkaido, especially because both Iwamura and Yanosuke Iwasaki, who hoped to be the buyer, were both originally from the Tosa han. Most newspapers opposed the sale, but at least one, Yukichi Fukuzawa's Jiji shinpo, supported it. Fukuzawa, it will be recalled, opposed public enterprises as obstacles to the development of private industry; he now insisted that the Imperial Household ought to divest itself of any business, land, and stock holdings it had, that imperial expenditures ought to be subject to parliamentary approval, and that the throne ought not to be involved in businesses of any kind.

Opposition to the proposed sale was also apparent in the Sado and Ikuno regions, whose residents feared that selling the mines to private 
parties would lead to successive resales and instability. When it was officially announced in May that the properties would indeed be sold, these people took to urging that the mines and the refinery at least be sold to local people. Then, when the government decided that the mines and the refinery had to be purchased together, they insisted on as much financial compensation as possible.

A set of eighteen regulations for the sale of the properties was issued on July 18; among other things, the regulations called for competitive bidding and immediate payment. They also stipulated that the properties go to the bidder whose price most exceeded the minimum set by the government; this minimum was not stated in the regulations, though Michitoshi Iwamura had already told newspapers that the three properties were worth $1,700,000$ yen.

Mitsubishi cautiously estimated the value of the properties at between $1,300,000$ and $1,600,000$ yen, based on a 956,000 yen value for the mines, 340,000 for the refinery, and an assumption that the mines could be exploited for thirty years and the annual rate of interest be $5 \%$. In any case, bidding began on September 16 amid rumors that the government's own assessment was actually low relative to the size of the mines and the quality of the equipment at the refinery and the immediate payment stipulation effectively limited the bidders to Mitsubishi, Mitsui, and Sumitomo. In the end, there were only two bidders; Mitsubishi's bid of $1,730,000$ yen was accepted, the second bidder having offered only $1,100,000$ yen. With this, Mitsubishi substantially expanded its nonferrous metal mining operations; it had acquired the Yoshioka Copper Mine in 1873, and had already tried to buy Sado and Ikuno in 1878.

\section{Sales to Mitsui.}

Mitsui's purchases of government properties consisted of the Shinmachi Spinning Mill, Miike Coal Mine, and Tomioka Filature. It also in 1913 purchased a majority of the stock of Hokkaido Tanko Kisen Kaisha running the Horonai Coal Mine, and in 1924 acquired what had been the Kamaishi Iron Works when its owner went bankrupt.

The Shinmachi Spinning Mill, located in Gunma prefecture, handled the spinning of waste silk. The brainchild of the Home Affairs Ministry, it opened in October 1877 with imported Swiss equipment; it later went under the jurisdiction of the Ministry of Agriculture and Commerce, and was the only profitable venture on the original list of government enterprises up for sale. The Ministry of Agriculture and Commerce approved one of the four bids submitted in 1881 , based on the amount of the bid and the bidder's prior experience in handling the mill's output; but the 
decision was overruled by the Finance Ministry, which wanted more money for the equipment at the mill. The Finance Ministry's action reflects the premium on money that marked the first disposal phase.

Shinmachi went up for sale again during the second phase of the government's disposal attempt, and this time was sold to Mitsui in 1887. Two other parties also bid on the mill, but Mitsui's offer was highest; moreover, Mitsui promised immediate payment, and obviously had the means to keep the operation going. Shinmachi was put under the auspices of Mitsui's Kanegafuchi Spinning Mill. ${ }^{14}$ )

Tomioka Filature was also among those operations put up for sale in 1881 , but at the time failed to elicit any bids. It already had a connection with Mitsui: Mitsui Bussan handled the sale of the filature's output on the Lyons market. The time required to send Tomioka receipts from sales in Lyons presented the filature with financial problems, since as a result it was often bereft of funds precisely when it needed to buy silkworm cocoons for reeling. This factor, among others, led to discussions within the government as to whether the filature should be closed down; the discussions lasted from April 1881, when Tomioka went under the jurisdiction of the Ministry of Agriculture and Commerce, to May 1882 , and resulted in a decision to keep the operation going with the apparent absence of a prospective buyer.

Even before 1881 there had been calls for the sale of Tomioka Filature - specifically, in May 1877, by Rokuro Hara, Eiichi Shibusawa, and Takashi Masuda. These same people were later to try, unsuccessfully, to buy the Shinmachi Spinning Mill. All were influential men: Hara, who later became president of the Yokohama Specie Bank, had used his financial activities to become friends with the directors of both Tomioka Filature and Doshinsha; Shibusawa, industrial pioneer in his own right, had been involved in the establishment of Tomioka; and Masuda was head of Mitsui Bussan.

In June 1891, bids were once again accepted for Tomioka; this time two Nagano prefecture residents submitted bids, but since neither met the government's minimum price the sale was halted. Bids were taken again in September 1893, at which time five parties were involved; they included Mitsui, whose bid of over 120,000 yen enabled it to acquire Tomioka. The price was low indeed, since two-thirds of it went for the silkworm cocoon reserves at the filature.

Mitsui was in the midst of an internal reorganization when it purchased Tomioka Filature. In April 1892, its mining operations, including that at Miike, were separated from Mitsui Bussan and put under a new entity, Mitsui Kozan (Mitsui Mining); in July of the next year, Mitsui Bus- 
san, Mitsui Kozan, Mitsui Bank, and Mitsui Gofuku-ten (Mitsui Dry Goods) were made unlimited partnerships. Factories formerly operated by Mitsui Bank and Mitsui Gofuku-ten were consolidated under a manufacturing department. Similarly, the silk-reeling operations at Tomioka and Oshima, the spinning mills at Shinmachi and Maebashi, and the Shibaura Seisakusho (Shibaura Machine Works) (one antecedent of Toshiba) were also put under this department, and new filatures were set up in Nagoya and Mie. These organizational changes were spearheaded by managing director Hikojiro Nakamigawa, and marked the beginning of Mitsui's own development as an industrial empire.

At Tomioka, Mitsui replaced the original, and now outdated, French equipment with reeling frames designed and built in Japan (i.e. .the Minorikawa frame), ended the filature's dormitory system in favor of a work force that commuted daily, and made the operation profitable. But with the exception of Tomioka and the Shinmachi Spinning Mill, the operations under Mitsui's manufacturing department failed to show profits, and the department was abolished in November 1898. And after the death of Nakamigawa in 1901, consideration began to be given to the idea of selling off Tomioka Filature and other factories. Takashi Masuda noted at a Mitsui Bussan meeting that the company's New York office was continually unable to get enough raw silk to meet demands on the American market. Supplying this demand had, in fact, been the incentive for Mitsui's acquisition of silk-reeling factories. But, Masuda said, these filatures were no real quantitative match for the thousands of farm families who reeled silk thread by hand in their homes; relying on the latter would, he suggested, ensure an adequate future supply. Masuda's opinion won the day: in August 1902, the filatures at Tomioka, Oshima, Nagoya, and Mie were sold to Hara Gomei Kaisha, a Yokohamabased silk-trading firm. Hara in turn later sold them to Katakura SilkReeling Company, which continues to operate Tomioka Filature.

Mitsui's connection with the Miike Coal Mine began in September 1876, when Mitsui Bussan, established two months earlier, was given sole rights to sell the mine's output overseas; Mitsui Bussan thereupon laid its emphasis on handling coal. In January 1879, Mitsui asked for, and received, an appropriation from the government to cover the cost of purchasing an additional ship and constructing coal storage facilities. At the same time, it renewed its Miike contract with the Bureau of Mining; the terms of the contract provided that profits be shared equally by Mitsui and the government. Mitsui, it is worth noting, handled exports of Miike's output mainly to Shanghai itself, while Mitsubishi still relied partly on Jardine, Matheson and Company to handle the output 
of its Takashima mine.

The regulations for the sale of the Miike Coal Mine were issued on April 21, 1888; they stated, to the surprise of many, that the mine was worth 4,000,000 yen and would not be undersold, and that an immediate payment of $1,000,000$ yen was necessary, with the balance to be paid over fourteen years. The high price demanded, and the short payment period, were in sharp contrast to terms set down by the government for its other enterprises; and they were, I think, more political than economic in inspiration. Popular criticism of public enterprises as obstacles to the development of private industry was as widespread as ever, and the government was eager to dispose of its remaining holdings before the Diet opened in 1890. The Foreign Minister at this time, Shigenobu Okuma, was an especially fervent advocate of this approach. But Finance Minister Masayoshi Matsukata opposed it, and it seems likely that he demanded the high price and stringent terms in the hope that the sale would be unsuccessful.

Bids for Miike were accepted on July 30,1888. Four parties submitted bids. Of these, two, including the highest, Hachiro Sasaki, were made by secret Mitsui representatives; the lowest bid was made by Mitsui's formal representative; the remaining, second-highest bid, was submitted by a party operating secretly on Mitsubishi's behalf. Apparently, Mitsui gambled that the high price would discourage any bidders other than its own, in which case it planned to have its two highest bids withdrawn and thereby acquire Miike for a relatively low price. The presence of Mitsubishi's representative foiled the scheme; Mitsui, after failing to persuade Mitsubishi's representative to act on its behalf, ended up buying Miike at the highest price bid. The final price, 4,555,000 yen, was a mere 2,300 yen more than Mitsubishi had offered.

In August, Mitsui requested that Miike's entire operation be placed immediately under its auspices, with Hachiro Sasaki as its guarantor; the mine was formally sold to Mitsui in January 1889 . Poor management made that year a less than favorable one for the Mitsui Bank: it was said that its capital assets were valued at only five million yen. However, Takashi Masuda, president of Mitsui Bussan, borrowed one million yen from Mitsui Bank to cover immediate payment. Many believed that the Miike purchase represented an unreasonable risk in the slump of the coal market at that time, and questioned Masuda's judgment in engineering the acquisition. The final price, in fact, was even higher than anticipated, because Mitsui had to pay an additional 35,000 yen for material at Miike, as well as an annual tax of over 15,000 yen.

Nor was the Miike operation itself free of problems. A major earth- 
quake in July 1889 effectively shut down the Kattate shaft, whose output amounted to an estimated one-third of Miike's total. Mitsui immediately asked the government to bear the expenses to open a new shaft and to reduce the price for the annual installment by 326,000 yen. Finance Minister Matsukata successfully opposed the request, citing the regulations of sale which prohibited postponing payments, reducing the price, or granting discounts. Kowashi Inoue, Director General of the Cabinet Legislation Bureau, favored Mitsui, as did Minister of Agriculture and Commerce Munemitsu Mutsu. Kaoru Inoue, Minister of Agriculture and Commerce at the time of the sale and the man who directed the House of Mitsui enacting the Mitsui family constitution in 1900, and was known as Mitsui's "guardian," suggested privately that any losses incurred were Mitsui's own since it became sole owner of Miike once the sale had gone through. This approach did confirm Mitsui's rights of ownership. In any case, Mitsui completed its payments for the mine in 1902.

\section{Conclusion}

The Ministries of Industry, Home Affairs, and Agriculture and Commerce were the institutional means through which the Meiji government attempted to accelerate industrialization in Japan. In fact, the Ministry of Industry aimed less at encouraging the development of industry in general than at ensuring that the government had at its disposal those elements of modern industry deemed essential for the state; thus the concentration on railroads and mines, and other heavy industries. Nevertheless, enterprises run by this ministry, when sold, did more to encourage industrial growth than those run by the Ministry of Home Affairs. This latter ministry concerned itself mainly with agriculture, cattle raising, light industries, and the like - in other words, with the modernization of industries that already existed in Japan. As a result, its activities often did little more than compete with traditional operations; with the exception of its assistance to Mitsubishi's shipping activities, it was not notably effective in encouraging the development of modern industries. The Ministry of Agriculture and Commerce, the last of these three ministries to be established, in effect took over what was left of the governments schemes to promote industry, and adopted a policy of indirectly protecting those industries under its jurisdiction - a role very similar to that played today by the Ministry of Agriculture, and by the Ministry of International Trade and Industry (MITI).

The period we have considered was not the most ideal of atmos- 
pheres: the financially insecure government had to face domestic unrest, the assassination of Toshimichi Okubo, the withdrawal of Shigenobu Okuma, and dissension within its own ranks; thus the trial-and-error approach to industrial policy. All public enterprises set up for the express purpose of encouraging industrialization were in place by 1881. Later public enterprises - e.g., the construction of the Yawata Iron Works in 1901, the nationalization of the main rail lines in 1906, the establishment of the tobacco and salt monopolies in 1904 and 1905, respectively - were built for other reasons.

Powerful business organizations like Mitsubishi and Mitsui benefited handsomely from the sale of public enterprises, and their purchases were important factors in their subsequent growth. They were able, after all, to acquire operations thanks to their own capacities. The role of the government in promoting industrialization consisted of setting up these enterprises and seeing that they were properly sold to the well-developed independent entrepreneurs. It was a limited role, to be sure. Although the sales frequently amounted to "gifts" to private industry, once the government disposed of its properties it rarely offered much in the way of additional financial support. This pattern of limited public assistance, so apparent in the establishment and disposal of the government's enterprises, was a characteristic feature of industrialization in Japan.

The seisho who purchased the government's properties were not, by and large, ordinary businessmen. Most of them had substantial prior experience in mining and manufacturing before acquiring public enterprises; they were already modern entrepreneurs, and they were to become the bulwarks of Japan's economy. Their acquisition of government enterprises represented less a sale or abandonment of these operations on the government's part than simply a transfer to those most capable of keeping them running. In the end, the major beneficiary of the sale of public enterprises was not the government, but private industry.

Although Mitsubishi and Mitsui profited most as a result of the government's actions, the ability of even these organizations to achieve stability and a sound basis for growth required, to a certain degree, the development of the Japanese economy as a whole. Still, both were aided immensely by the fact that they had, earlier than other business organizations, embarked on a policy of diversification. Thus, they were able to absorb the factories and mines they acquired from the government into their structures with a minimum of difficulty; and the acquisitions themselves facilitated the process of diversification.

Between 1886 and 1893, Mitsubishi's mining operations accounted for fully 47.6 percent of its gross earnings; its coal mines alone accounted 
for 40.7 percent; at the same time, shipbuilding yielded a mere 4.2 percent. The Nagasaki Shipyard was ridiculed as a "coal wagon factory" for Mitsubishi's coal mines, and profits there were low except during the wars with China and Russia. For the 1894-1917 period, mining operations accounted for 57.5 percent of Mitsubishi's earnings. ${ }^{15)}$ But shipbuilding revenues did account for a steadily higher percentage of profits once Mitsubishi invested heavily in this area following the passage of laws to promote shipping and shipbuilding in 1896. Mitsubishi's shipyards were able to become the sole contractors for the Nihon Yusan Kaisha, a Mitsubishi subsidiary; and between 1897 and 1912, they obtained 66 percent of all public funds disbursed to the shipbuilding industry (the Kawasaki Shipyard, by contrast, got 26 percent). Mitsubishi's investments in its shipbuilding operations paid off not only here, but during World War I as well, when orders for ships skyrocketed.

The acquisition of the shipyard at Nagasaki led, in time, to the development of Mitsubishi's electric machinery, aircraft, and optics operations. Mitsubishi built the Zero fighters and the huge battleship Musashi during World War II; in this period, the paid-up capital assets of its manufacturing sectors were the highest in the nation. Still, Mitsubishi remains an industrial giant, with particular influence in the areas of manufacturing, mining, and finance.

The acquisition of the Miike Coal Mine represented Mitsui's first major venture into a production enterprise; prior to this, it had concentrated on trade and finance. Its coal mining revenues were soon the highest in Japan, and helped Mitsui move into the chemical industry more quickly than Mitsubishi. The predominance of Mitsui's coal interests meant that, as of 1907 , it was responsible for 90 percent of all coal exported from Japan; its coal shipments were substantial enough to prompt the development of Mitsui's shipping, and then shipbuilding divisions. Mitsui thus moved from a pre-Meiji concentration on financial and commercial activities into mining and manufacturing.

There were eight major zaibatsu in prewar Japan: Mitsui, Mitsubishi, Sumitomo, Yasuda, Asano, Okura, Furukawa and Kawasaki (i.e., the financial organization other than the shipbuilding company mentioned earlier). Except for Sumitomo, Yasuda and Kawasaki, five of them acquired government enterprises, and used their revenues as a basis to expand into major industrial organizations. This reflects the fact that, in the early Meiji years, profits were obtainable only from industries like mining (something the Meiji government itself discovered).

Whether private industry could have developed as it did had the government not sold its enterprises in the way described here is question- 
able. At present, Japan and the United States are the only non-socialist nations with few nationalized industries ${ }^{16}$ ); as such, they have avoided the large public bureaucracies and other economic handicaps that burden nations with a substantial number of nationally-owned enterprises. The Meiji government's decision to divest itself of its industrial activities is in a large measure the reason for Japan's present economic system. Today, the only nationalized industry in Japan is the Japan National Railway. Interestingly enough, this operates at a loss and is noted for its inefficiency; and there is discussion as to whether it should be made private.

\section{Notes}

1) Keieishigaku (Japan Business History Review) vol. 6 no. 1 (1971), p. $69-94$.

2) Masaaki Kobayashi, Nihon no kogyoka to kangyo haraisage: seifu to kigyo (Japan's Early Industrialization and the Transfer of Government Enterprises: Government and Business), Toyo Keizai Shinposha, 1977.

3) Keiichiro Nakagawa, ed., Government and Business, University of Tokyo Press, 1980.

4) Thomas C. Smith, Political Change and Industrial Development in Japan: Government Enterprises, 1868-1880, Stanford: Stanford University Press, 1955.

5) A Ministry of Civil Affairs was established prior to this, in April 1869; among other things, this ministry was intended to handle the postal system, water works, and stock farming.

6) Okuma monjo (Documents Relating to Shigenobu Okuma), A2, A455, Waseda Daigaku Shakai Kagaku Kenkyusho (Institute of Social Sciences, Waseda University).

7) The Senju Textile Mill, which produced wool cloth, was subsequently put under the control of the War Ministry. See Masaaki Kobayashi, "Senju seijujo no haraisage mondai" (Problems in the Transfer of the Senju Textile Mill), in Moriaki Tsuchiya and Hidemasa Morikawa, eds., Kigyosha katsudo no shiteki kenkyu (Historical Studies of Entrepreneurial Activities) Nihon Keizai Shinbunsha, 1981.

8) Takafusa Nakamura and Mataji Umemura, eds., Matsukata zaisei to shokusan kogyo seisaku (Matsukata Fiscal Policy and the Policy of Industrial Promotion) University of Tokyo Press, 1983.

9) Yasuo Mishima, Hanshin Zaibatsu (Zaibatsu in Osaka and Kobe), Nihon Keizai Shinbunsha, 1984. 
10) Masaaki Kobayashi, Yawata seitetsujo (The Yawata Iron Works) Kyoikusha, 1977.

11) Kanji Ishii, Kindai Nihon to Igirisu shihon (Modern Japan and British Capital) University of Tokyo Press, 1984, p. 345.

12) Masaaki Kobayashi, "Mitsubishi no kenkyushi" (A Report on Research on Mitsubishi), Keizaikei (Quarterly Journal of the Economic Society of Kanto Gakuin University), no. 117, Kanto Gakuin University, 1978, p. 67.

13) Iwasaki Yataro - Yanosuke Dneki Hensaikai, ed., Iwasaki Yanosuke den (A Biography of Yanosuke Iwasaki), vol. 2, 1971, p. 278.

14) Masaaki Kobayashi, "Shinmachi bosekijo no haraisage" (The Transfer of the Shinmachi Spinning Mill), Keizaikei, no. 119, 1978, p. $51-66$.

15) Kobayashi, Nihon no kogyoka to kangyo haraisage: seifu to kigyo, pp. 373-374.

16) "Capitalism: Is It Working?," Time, 21 April 1980.

Translated by Stephen W. McCallion 